\title{
Diversity of the Mesostigmata (Acari) in tree-hollows of selected deciduous tree species
}

\author{
SŁAWOMIR KACZMAREK, TOMASZ MARQUARDT \\ and KATARZYNA FALEŃCZYK-KOZIRÓG \\ Kazimierz Wielki University, Institute of Environmental Biology, Department of Zoology, \\ Ossolińskich Av. 12, PL-85-094 Bydgoszcz, Poland \\ Corresponding author: Sławomir Kaczmarek, slawkacz@ukw.edu.pl
}

(Received on 31 January 2008; Accepted on 21 December 2010)

\begin{abstract}
Rich gamasid communities were found in tree-hollows of horse chestnut (Aesculus hippocastanum), small-leaved lime (Tilia cordata), and white willow (Salix alba) in urban and rural areas in northern Poland (Bydgoszcz and its environs). We recorded there 93 gamasid species of 21 families in a total of 18 tree-hollows. Differences in the dominance structure of gamasid communities at the levels of family and species indicated dissimilarities in the mite communities, depending on tree species and intensity of human impact. The chestnut tree-hollows in both areas were dominated by mites of the family Urodinychidae (with the dominant Uroobovella pyriformis in both cases). The lime tree-hollows were colonized mostly by the Trematuridae (Trichuropoda ovalis) and the Digamasellidae (Dendrolaelaps tenuipilus) in the rural area, whereas by the Ascidae (Iphidozercon gibbus) in the city. The gamasid communities of willow hollows were dominated by the Trematuridae (Trichouropoda ovalis) in the urban area, and by the Digamasellidae (Dendrolaelaps longifallax, D. zwoelferi) in the rural area. Some rare species (e.g. Microgynium rectangulatum or Microsejus truncicola) were also recorded, mostly in the rural area.
\end{abstract}

Keywords: Acari, Gamasida, ecology, tree-hollows, urban area

\section{INTRODUCTION}

Natural tree-hollows are unique microhabitats forming conditions suitable for the development of many species with a narrow range of ecological tolerance (GuTOwsKi et al. 2004). Removing the decaying wood from the hollows, which is a relatively common practice, simultaneously eliminates the microhabitats of species associated with decomposing wood, including rare, vulnerable, and endangered species. Acarological works concerning the microhabitats of decomposing wood are relatively scarce and cover the microhabitats of tree-hollows, dead logs, stumps, and barkbeetle feeding grounds (Moser \& Roton 1971; KieŁczewsKi \& WiśniewsKi 1983; Moser \& Bogenshütz 1984; Michalski et al. 1985, 1992, 1992a; Moser et. al. 1989, 
KaczMareK et al. 1992; KacZMAReK \& Michalski 1994; Gwiazdowicz 1999; KaCZMAREK \& MARQuARDT 2004; SŁomian \& MAdej 2006). Most of the available information on the occurrence of particular gamasid species in dead wood can be found in faunistic studies based on qualitative samples collected from various types of microhabitats (e.g. Skorupski \& Gwiazdowicz 1996; Gwiazdowicz et al. 1999, 2001; Gwiazdowicz \& Szadkowski 2000; Skorupski 2000; Gwiazdowicz \& Fabrowski 2001; BŁoszyK et al. 2002). There are completely no scientific papers concerning the comparison of mite communities appearing in tree-hollows within urban and rural areas.

The aim of this research was to compare mite communities of the order Gamasida within decaying wood in tree-hollows of 3 deciduous tree species (Aesculus hippocastanum, Salix alba and Tilia cordata) in urban and rural areas, as well as broadening the knowledge of the ecology of selected gamasid species.

\section{MATERIAL AND METHODS}

The research was carried out in northern Poland, in the urban area of Bydgoszcz and in a rural area at a distance of $30 \mathrm{~km}$ from the city, near the town of Kcynia. The samples of decayed wood were collected from tree-hollows of 3 deciduous tree species: horse chestnut (Aesculus hippocastanum), white willow (Salix alba), and small-leaved lime (Tilia cordata) in May and June 2005. The material was acquired from 6 tree-hollows of each tree species: 3 from the urban and 3 from the rural area. The mites were extracted from the samples by using modified Tullgren funnels for 6 days, next preserved in $70 \%$ ethyl alcohol, and finally mounted in Hoyer's medium. Altogether, 682 samples of $50 \mathrm{~cm}^{3}$ each were collected, and 9006 specimens of the Gamasida (including 58\% adult individuals) were extracted from them. The zoocenological analysis was based on the indices of abundance (individuals per sample of $50 \mathrm{~cm}^{3}$ ), dominance (D, \% of the total catch), and constancy $(\mathrm{C}, \%$ of the total no. of samples), together with their dominance structure (BŁoszYK 1999) as well as number of species, Shannon species diversity index, and Pielou's evenness index of the communities.

\section{RESULTS}

Overall, 93 species of the Gamasida, belonging to 21 families, were recorded within the study areas. They include 74 species in the city and 61 in the rural area. In the urban area, the number of species within the horse chestnut and willow treehollows ( $\mathrm{S}=47$ and $\mathrm{S}=48$, respectively) (Table 1), was over twice as high as that in the lime tree-hollows $(\mathrm{S}=23)$. In the rural area, the largest number of species of the studied mites was recorded in the lime tree-hollows $(S=42)$, whereas the other microhabitats were approximately $25 \%$ poorer in species $(S=32)$. In the chestnut tree and willow tree-hollows, the abundance of the Gamasida proved to be higher in the city. By contrast, in the lime trees, their abundance in the rural area was more than twice as high as in the city. The species diversity of gamasid communities found 
Table 1. General abundance (individuals per sample of $50 \mathrm{~cm}^{3}$ ), number of species, species diversity $\left(H^{\prime}\right)$, and species evenness $\left(J^{\prime}\right)$ of Gamasida in tree-hollows of the studied species $(\mathrm{Ah}=\mathrm{AesCu}$ lus hippocastanum, $T c=$ Tilia cordata, $S a=$ Salix alba) within an urban area (I) and rural area (II)

\begin{tabular}{lrrrrrr}
\hline & \multicolumn{2}{c}{ Horse chestnut $(A h)$} & \multicolumn{2}{c}{ Small-leaved lime $(T c)$} & \multicolumn{2}{c}{ White willow $(\mathrm{Sa})$} \\
\cline { 2 - 7 } & \multicolumn{1}{c}{$\mathrm{I}$} & \multicolumn{1}{c}{ II } & \multicolumn{1}{c}{ I } & \multicolumn{1}{c}{ II } & \multicolumn{1}{c}{ I } & \multicolumn{1}{c}{ II } \\
\hline Mean abundance & 26.81 & 18.42 & 3.10 & 6.78 & 17.56 & 5.38 \\
No. of species & 47 & 32 & 23 & 42 & 48 & 32 \\
Diversity $\left(H^{\prime}\right)$ & 1.632 & 2.088 & 2.031 & 2.850 & 2.438 & 2.435 \\
Evenness $\left(J^{\prime}\right)$ & 0.424 & 0.602 & 0.648 & 0.763 & 0.630 & 0.703 \\
\hline
\end{tabular}

Table 2. Dominance structure of selected families of Gamasida in tree-hollows of the studied species $($ Ah $=$ Aesculus hippocastanum; $T c=$ Tilia cordata; $S a=$ Salix alba $)$ within an urban area (I) and rural area (II)

I

\begin{tabular}{|c|c|c|}
\hline Horse chestnut $(A h)$ & Small-leaved lime $(T c)$ & White willow $(\mathrm{Sa})$ \\
\hline \multicolumn{3}{|c|}{ eudominants } \\
\hline Urodinychidae (59.15\%) & Ascidae $(45.70 \%)$ & Trematuridae (34.24\%) \\
\hline \multicolumn{3}{|c|}{ dominants } \\
\hline \multirow{2}{*}{ Laelapidae (20.08\%) } & Trematuridae (16.94\%) & \multirow{2}{*}{ Urodinychidae (24.61\%) } \\
\hline & Laelapidae (15.86\%) & \\
\hline \multicolumn{3}{|c|}{ subdominants } \\
\hline \multirow{3}{*}{ Polyaspidae (7.58\%) } & \multirow{2}{*}{ Parasitidae $(9.41 \%)$} & Veigaiidae (14.90\%) \\
\hline & & Parasitidae (11.73\%) \\
\hline & \multicolumn{2}{|l|}{ II } \\
\hline Horse chestnut $(A h)$ & Small-leaved lime $(T c)$ & White willow $(\mathrm{Sa})$ \\
\hline \multicolumn{3}{|c|}{ eudominants } \\
\hline Urodinychidae (37.60\%) & - & Digamasellidae (31.50\%) \\
\hline \multicolumn{3}{|c|}{ dominants } \\
\hline Ascidae (19.14\%) & Trematuridae (27.06\%) & Laelapidae $(25.27 \%)$ \\
\hline Digamasellidae (18.87\%) & Digamasellidae (15.26\%) & Microgyniidae (21.60\%) \\
\hline \multicolumn{3}{|c|}{ subdominants } \\
\hline \multirow{3}{*}{ Parasitidae (13.44\%) } & Ascidae $(14.68 \%)$ & \multirow{3}{*}{ Parasitidae (10.17\%) } \\
\hline & Parasitidae (13.24\%) & \\
\hline & Laelapidae (11.27\%) & \\
\hline
\end{tabular}


Table 3. Dominance (D, \%), and constancy (C, \%) of selected Gamasida in tree-hollows of the studied species $(A h=$ Aesculus hippocastanum, $T c=$ Tilia cordata, $S a=$ Salix alba $)$ within an urban area (I) and rural area (II). The occurrence of other species is summarized under the table

\begin{tabular}{|c|c|c|c|c|c|c|c|c|c|c|c|c|}
\hline \multirow{3}{*}{ Species } & \multicolumn{4}{|c|}{ Horse chestnut $(A h)$} & \multicolumn{4}{|c|}{ Small-leaved lime $(T c)$} & \multicolumn{4}{|c|}{ White willow $(\mathrm{Sa})$} \\
\hline & \multicolumn{2}{|c|}{ I } & \multicolumn{2}{|c|}{ II } & \multicolumn{2}{|c|}{$\mathrm{I}$} & \multicolumn{2}{|c|}{ II } & \multicolumn{2}{|c|}{ I } & \multicolumn{2}{|c|}{ II } \\
\hline & $\mathrm{D}$ & $\mathrm{C}$ & $\mathrm{D}$ & $\mathrm{C}$ & $\mathrm{D}$ & $\mathrm{C}$ & $\mathrm{D}$ & $\mathrm{C}$ & $\mathrm{D}$ & $\mathrm{C}$ & $\mathrm{D}$ & $\mathrm{C}$ \\
\hline $\begin{array}{l}\text { Dendrolaelaps } \\
\text { disetosimilis } \\
\text { Hirschmann, } 1960\end{array}$ & & & 10.14 & 29.17 & & & 1.97 & 8.33 & & & & \\
\hline $\begin{array}{l}\text { D. longifalax } \\
\text { Hirschmann, } 1960\end{array}$ & 0.12 & 2.50 & 8.46 & 30.00 & & & & & 3.04 & 21.75 & 15.02 & 25.32 \\
\hline $\begin{array}{l}\text { D. tenuipilus } \\
\text { Hirschmann, } 1960\end{array}$ & & & & & & & 8.57 & 28.33 & & & & \\
\hline $\begin{array}{l}\text { D. zwoelferi } \\
\text { Hirschmann, } 1960\end{array}$ & & & & & & & & & & & 16.05 & 23.27 \\
\hline $\begin{array}{l}\text { Hypoaspis miles } \\
\text { (Berlese, 1892) }\end{array}$ & 17.81 & 44.17 & 5.02 & 37.50 & & & 1.17 & 6.25 & 2.31 & 28.73 & 15.71 & 27.38 \\
\hline $\begin{array}{l}\text { Iphidozercon } \\
\text { gibbus } \\
\text { Berlese, } 1903\end{array}$ & 1.62 & 15.83 & 18.60 & 40.00 & 44.62 & 21.67 & 3.69 & 14.17 & 0.38 & 5.00 & 0.14 & 0.76 \\
\hline $\begin{array}{l}\text { Microgynium } \\
\text { rectangulatum } \\
\text { Trägardh, } 1942\end{array}$ & & & & & & & 0.25 & 0.83 & & & & \\
\hline $\begin{array}{l}\text { Microsejus } \\
\text { truncicola } \\
\text { Trägardh, } 1942\end{array}$ & & & & & & & & & 0.40 & 3.51 & 21.60 & 29.33 \\
\hline $\begin{array}{l}\text { Polyaspis } \\
\text { patavinus } \\
\text { Berlese, } 1881\end{array}$ & 7.58 & 32.50 & 0.14 & 2.50 & & & 0.25 & 1.67 & 2.37 & 23.33 & & \\
\hline $\begin{array}{l}\text { Proctolaelaps } \\
\text { pygmaeus } \\
\text { (Müller, 1860) }\end{array}$ & 0.16 & 3.33 & 0.09 & 1.67 & & & 10.23 & 32.92 & 0.09 & 1.67 & 0.58 & 3.14 \\
\hline $\begin{array}{l}\text { Paragamasus } \\
\text { runciger } \\
\text { (Berlese, 1903) }\end{array}$ & 3.45 & 23.33 & 0.23 & 3.33 & 8.33 & 12.50 & 2.46 & 10.00 & 4.32 & 16.67 & 7.17 & 25.68 \\
\hline Parasitus sp. & 0.71 & 13.33 & 6.15 & 34.17 & & & 9.18 & 35.63 & & & 1.47 & 7.90 \\
\hline $\begin{array}{l}\text { Trichouropoda } \\
\text { karawaiewi } \\
\text { (Berlese, 1904) }\end{array}$ & 0.06 & 1.67 & & & 16.40 & 33.33 & 2.24 & 13.33 & 6.65 & 47.41 & 4.67 & 16.99 \\
\hline $\begin{array}{l}\text { T. ovalis } \\
\text { (C.L. Koch, 1839) }\end{array}$ & & & 0.36 & 5.00 & & & 24.82 & 32.50 & 27.54 & 32.50 & 1.49 & 7.27 \\
\hline $\begin{array}{l}\text { Uroobovella } \\
\text { pulchella } \\
\text { (Berlese, 1904) }\end{array}$ & & & 0.05 & 0.83 & & & & & 19.37 & 56.62 & & \\
\hline
\end{tabular}




\begin{tabular}{|c|c|c|c|c|c|c|c|c|c|c|c|c|}
\hline $\begin{array}{l}\text { U. pyriformis } \\
\text { (Berlese, 1920) }\end{array}$ & 57.66 & 94.17 & 36.02 & 46.67 & 1.34 & 4.17 & 0.89 & 6.04 & 0.29 & 5.00 & & \\
\hline $\begin{array}{l}\text { Veigaia } \\
\text { nemorensis } \\
\text { (C.L. Koch, 1839) }\end{array}$ & 0.03 & 0.83 & & & & & 2.49 & 11.04 & 14.27 & 59.65 & 0.46 & 2.50 \\
\hline
\end{tabular}

Ameroseiidae: Amerosejus plumea Oudemans, 1930, Ah(I,II),Tc(II); Ascidae: Aceosejus muricatus (C.L. Koch, 1839) Sa(I); Arctoseius cetratus (Sellnick, 1940) Ah(I,II),Tc(I, II),Sa(I); Asca nova Willmann, 1939, Tc(I); Cheiroseius sp. Ah(I),Tc(I); Gamasellodes bicolor (Berlese, 1918) Tc(II),Sa(I,II); Lasioseius youcefi Athias-Henriot, 1959, Ah(I); Neojordensja levis (Oudemans et Voigts, 1904) Ah(I); Platyseius subglaber (Oudemans, 1902) Ah(I),Sa(I); Proctolaelaps sp. Ah(I,II),Tc(II),Sa(I), Zerconopsis apodius Karg, 1969, Sa(I); Celaenopsidae: Celaenopsis badius C.L. Koch, 1839, Ah(I),Tc(I,II),Sa(I); Digamasellidae: Dendrolaelaps euarmatus Hirschmann, 1960, Ah(I),Sa(I); D. posnaniensis Wiśniewski et Hirschmann, 1984, Ah(I,II),Sa(I); D. quadrisetus (Berlese, 1920) Ah(I,II),Tc(I,II), D. rectus Karg, 1962, Sa(I); Dendrolaelaps sp. Ah(I), Tc(II),Sa(II); Eviphididae: Alliphis siculus (Oudemans, 1905) Ah(I,II),Tc(I,II),Sa(II); Eviphis ostrinus (C.L. Koch, 1836) Ah(II); Halolaelapidae: Leitneria pugio (Karg, 1961) Tc(II); Laelapidae: Eulaelaps stabularis (C.L. Koch, 1839) Ah(I),Sa(II); Haemogamasus sp. Ah(I); Hirstionyssus carnifex (Oudemans, 1913) Ah(I,II),Sa(II), Hypoaspis aculeifer (Canestrini, 1883) Ah(I,II),Tc(I,II),Sa(I,II); H. angusta Karg, 1965 Ah(I),Tc(I,II); H. austriaca Sellnick, 1935, Tc(I,II),Sa(II); H. cuneifer (Michael, 1891) Ah(I),Tc(II); H. praesternalis Willmann, 1949, Ah(I,II),Tc(I,II),Sa(I,II); H. vacua (Michael, 1891) Ah(I,II),Tc(I),Sa(I,II); Hypoaspis sp. Tc(II); Laelaps agilis C.L. Koch, 1836, Tc(II); Macrochelidae: Geholaspis longispinosus (Kramer, 1876) Sa(I); Macrocheles sp. Ah(I),Tc(I),Sa(I); Pachylaelapidae: Pachylaelaps magnus Halbert, 1915, Sa(I); P. pectinifer (G. et R. Canestrini, 1882) Tc(I,II),Sa(I,II); Pachylaelaps sp. Sa(I); Pachyseius humeralis Berlese, 1910, Sa(II); Parasitidae: Holoparasitus excipuliger (Berlese, 1905) Sa(I); Leptogamasus lobatus (Willmann, 1951) Sa(I); L. suecicus Trägardh, 1936, Ah(I),Tc(II),Sa(I); Paragamasus misellus (Berlese, 1903) Ah(I),Tc(I,II),Sa(I); P. robustus (Oudemans, 1902) Ah(I); P. runcatellus (Berlese, 1903) Tc(II); Paragamasus sp. Sa(II); Parasitus sp.2 Ah(II); Pergamasus crassipes (Linnae, 1758) Ah(I,II),Tc(I,II),Sa(I,II); P. septentionalis (Oudemans, 1902) Sa(I); Pergamasus sp. Tc(II),Sa(I), Vulgarogamasus kraepelini (Berlese, 1904) Ah(I,II),Tc(I,II),Sa(I); Phytoseiidae: Amblyseius sp. Ah(I), Typhlodromus sp. Tc(II); Polyaspidae: Uroseius infirmus (Berlese, 1887) Ah(II),Tc(II); Rhodacaridae: Cyrtolaelaps mucronatus (G. et R. Canestrini, 1881) Ah(II),Tc(I),Sa(II); Cyrtolaelaps sp. Ah(II);Tc(II); Euryparasitus emarginatus C.L. Koch, 1839, Ah(I); Rhodacarellus silesiacus Willmann, 1936, Sa(II); R. subterraneus Willmann, 1935, Ah(I),Tc(II); Rhodacarellus sp. Sa(I); Rhodacarus coronatus Berlese, 1921, Ah(I),Sa(II); Rhodacarus sp. Sa(II); Sejidae: Sejus posnaniensis Hirschmann et Kaczmarek, 1991, Ah(I); Trachytidae: Trachytes aegrota (C.L. Koch, 1841) Ah(I),Sa(I); Trematuridae: Trichouropoda elegans (Kramer, 1882) Tc(I),Sa(I); Urodinychidae: Dinychus perforatus Kramer, 1886, Ah(II),Tc(II),Sa(I,II); Uroobovella obovata (Canestrini et Berlese, 1884) Ah(I,II),Tc(I),Sa(I,II); U. vinicolora (Vitzhum, 1926) Ah(I,II); Uropodidae: Uropoda orbicularis (Müller, 1776) Ah(I); Uropoda sp. Ah(I); Veigaiidae: Gamasolaelaps excisus (C.L. Koch, 1879) Ah(I); Veigaia cerva (Kramer, 1876) Tc(II),Sa(I,II); V. exigua (Berlese, 1916) Sa(I); V. kochi (Trägardh, 1901) Tc(II); V. planicola (Berlese, 1892) Sa(I); Veigaia sp. Sa(I); Zerconidae: Prozercon sp. Sa(I); Zercon sp. Sa(II).

in the decaying tree-hollows of chestnut trees and lime trees was higher in the rural area, whereas the willow decay showed similar values in both areas. The evenness of the studied mite communities in all cases proved to be higher in the rural area. In the horse chestnut trees in both examined areas, the family Urodinychidae was classified as eudominants $(\mathrm{D}=59.15 \%$ in the rural area and $\mathrm{D}=37.60 \%$ in the city) (Table 2 ). 
In the lime trees outside the city, there were no recorded eudominants, and the families of Trematuridae and Digamasellidae were classified as dominants $(D=27.06 \%$ and $\mathrm{D}=15.26 \%$, respectively). In lime trees in the urban area, the family Ascidae was classified as eudominants $(\mathrm{D}=45.70 \%)$. In the willow trees, species of the family Trematuridae were dominant in the city $(\mathrm{D}=34.24 \%)$, whereas outside the city, representatives of the Digamasellidae were the most numerous ( $D=31.50 \%$ ).

The species that dominated the gamasid communities in the horse chestnut treehollows in both of the researched areas proved to be Uroobovella pyriformis (Tables 3 and 4). That species was a eudominant in both the urban and rural areas, reaching $57.66 \%$ and $36.02 \%$ of the total catch, respectively. In the lime trees in the urban

Table 4. Dominance structure of selected species of Gamasida in tree-hollows of the studied species $($ Ah $=$ Aesculus hippocastanum, $T c=$ Tilia cordata,$S a=$ Salix alba $)$ within an urban area (I) and rural area (II)

I

\begin{tabular}{ccc}
\hline Horse chestnut $(A h)$ & Small-leaved lime $(T c)$ & White willow $(S a)$ \\
\hline U. pyriformis $(57.66 \%)$ & I. gibbus $(44.62 \%)$ & - \\
\hline dominants & T. ovalis $(27.54 \%)$ \\
H. miles $(17.81 \%)$ & T. karawaiewi $(16.40 \%)$ & U. pulchella $(19.37 \%)$ \\
\hline P. patavinus $(7.58 \%)$ & subdominants & V. nemorensis $(14.27 \%)$ \\
\hline
\end{tabular}

II

\begin{tabular}{ccc}
\hline Horse chestnut $(A h)$ & Small-leaved lime $(T c)$ & White willow $(\mathrm{Sa})$ \\
\hline & eudominants & - \\
\hline U. pyriformis $(36.02 \%)$ & - & D. longifallax $(15.02 \%)$ \\
& dominants & H. miles $(15.71 \%)$ \\
I. gibbus $(18.60 \%)$ & D. ovalis $(24.82 \%)$ & D. zwoelferi $(16.05 \%)$ \\
& & M. truncicola $(21.60 \%)$ \\
\hline & subdominants & \\
\hline D. longifallax $(8.46 \%)$ & D. tenuipilus $(8.57 \%)$ & \\
\hline D. disetosimilis $(10.14 \%)$ & Parasitus sp. $(9.18 \%)$ & \\
& P. pygmaeus $(10.23 \%)$ & \\
\hline
\end{tabular}


area, the most numerous was Iphidozercon gibbus $(\mathrm{D}=44.62 \%)$, classified as a eudominant. Outside the city, there were no eudominants in the lime trees, while the dominant was Trichouropoda ovalis $(\mathrm{D}=24.82 \%)$. In the willow trees, no eudominants were recorded. T. ovalis and Uroobovella pulchella were dominants in the urban area $(\mathrm{D}=27.54 \%$ and $\mathrm{D}=19.37 \%$ respectively), whereas outside the city, that class included Dendrolaelaps longifallax $(\mathrm{D}=15.02 \%)$, D. zwoelferi $(\mathrm{D}=16.05 \%)$, Hypoaspis miles $(\mathrm{D}=15.71 \%)$, and Microsejus truncicola $(\mathrm{D}=21.60 \%)$.

\section{DISCUSSION}

The high number of recorded species reflects the role of decaying wood in treehollow microhabitats in the shaping of mite species diversity. We identified 93 species of the Gamasida in the material collected from 18 tree-hollows of 3 deciduous tree species found within the study areas. For comparison, 270 Gamasida species recorded to date within the whole area of the Białowieża National Park (GwIAZDOwicz et al. 1999, 2001; BŁoszYK et al. 2002), 260 species within the Wielkopolska National Park (SKORUPSKi 2000), and 252 species in the Pieniny National Park (SKORUPSKi \& GwiazDowicz 1996).

On the one hand, the lower values of species diversity and evenness of the examined mite communities in the urban area might indicate a negative influence of human activity on communities of the studied mites in the decaying wood of treehollows. On the other hand, a higher density and number of Gamasida species were recorded in the horse chestnut tree and willow tree-hollows found in the urban area. The diversified influence of the urban environment on mite community parameters has been already documented (NiEDBAŁa et al. 1990). Obviously, the influence of unique conditions of urban environments can be both limiting and stimulating.

The differences in gamasid community dominance structure at the levels of family and species pointed to some variation of the studied mite communities depending on tree species and intensity of human impact. Simultaneously, the aforementioned differences show the simplification in the structure of the communities of the tree-hollows found within urban areas. A larger share of the species belonging to the family Digamasellidae within the rural area (Dendrolaelaps longifallax), or their occurrence exclusively outside the city (Dendrolaelaps disetosimilis, D. tenuipilus, D. zwoelferi), might prove their sensitivity to human pressure in the urban areas. Similarly, the occurrence of rare representatives of the family Microgyniidae, such as Microgynium rectangulatum and Microsejus truncicola, mainly associated with the microhabitats of decomposing wood (Bregetova 1977; SKorupsKi \& GwiAzdowicz 1996; Gwiazdowicz et al. 1999, 2001; Skorupski 2000; SŁomian \& Madej 2006), might indicate their preference towards uncontaminated environments.

A clear preference for the urban environment was observed in Trichouropoda karawaiewi. That species occurred in the horse chestnut trees exclusively in the urban area, whereas in the other tree-hollows it was observed in both examined areas, but reached higher values of abundance, dominance and constancy in the city. In the urban agglomeration of Poznań (KRYSIAK et al. 2002), populations of T. karawaiewi 
increased in abundance towards the city centre, while an opposite trend was recorded in T. ovalis. In the chestnut tree and lime tree-hollows in our study, that species occurred only outside the city, whereas it was present in the willow trees in both researched areas, but with a higher abundance in the city.

\section{CONCLUSIONS}

Our results presented in this paper concern only one type of microhabitat: treehollows. The number of identified species and families shows the richness of gamasid communities in decomposing wood. Tree-hollows of various tree species create distinct micro-environmental conditions and, as such, are characterised by the occurrence of distinct communities of the examined mites. What is more, the communities inhabiting tree-hollows of the same tree species differ depending on human impact. The influence of human pressure on the studied communities is an interesting phenomenon, which is both limiting (e.g. species diversity index or evenness index) and stimulating (e.g. number of species, abundance or biodiversity at the family level). Among the recorded species, there are some that avoided the polluted urban environment (e.g. some species of the family Digamasellidae) and some that preferred the areas of high human pressure (Trichouropoda karawaiewi). Dead wood of treehollows is also the habitat of some rare species, e.g. Microgynium rectangulatum or Microsejus truncicola.

\section{REFERENCES}

BŁoszYK J. 1999. Geograficzne i ekologiczne zróżnicowanie zgrupowań roztoczy z kohorty Uropodina (Acari, Mesostigmata) w Polsce. I. Uropodina lasów grądowych [Geographical and ecological diversity of mite communities of the cohort Uropodina (Acari, Mesostigmata) in Poland. I. Uropodina of oak-hornbeam forests]. Wyd. Kontekst, Poznań (in Polish).

BŁoszyk J., Bajaczyk R., BŁoszyk G., NapieraŁa A. 2002. Uropodina (Acari: Mesostigmata) parków narodowych Polski na tle innych obszarów [Uropodina (Acari: Mesostigmata) of Polish national parks compared to other areas]. Kosmos 51/4: 463-470 (in Polish).

BREGETOVA I.G. 1977. Opredelitel obitayushchikh w pochve kleshchei [Identification key to soilinhabiting mites Mesostigmata]. AN SSSR, Leningrad (in Russian).

Gutowski M., Bobiec A., Pawlaczyk P., Zub K. 2004. Drugie życie drzewa [Second life of a tree]. WWF Polska, Warszawa (in Polish).

Gwiazdowicz D. J. 1999. Mites (Acari, Gamasida) occurring in tree-hollows in the Białowieża National Park. AR Poznań, Forestry 2: 47-55.

Gwiazdowicz D. J., Fabrowski M. 2001. Mites (Acari, Gamasida) of the Ojców National Park. Par. Nar. i Rez. Przyr. 20: 35-46.

Gwiazdowicz D. J., Madej G., Błaszak C. 1999. Stan poznania roztoczy (Acari: Gamasida) Puszczy Białowieskiej [State of knowledge of mites (Acari: Gamasida) from Białowieża Forest]. Par. Nar. i Rez. Przyr. 18: 53-60 (in Polish). 
Gwiazdowicz D. J., Madej G., BŁaszak C. 2001. Gamasida without Uropodina. In: Catalogue of the fauna of Białowieża Primeval Forest (Gutowski M., Jaroszewicz B., Eds), pp. 65-68, IBL Warszawa.

Gwiazdowicz D. J., Szadkowski R. 2000. Mites (Acari, Gamasida) of the Narew National Park. Fragm. Faun. 43: 91-95.

Kaczmarek S., Marquardt T. 2004. Gamasida (Acari) in rotten hollows of broad-leaved trees of selected species in the city of Bydgoszcz (Poland). In: Fauna miast Europy Środkowej 21.wieku (IndyKiewicz P., BarczaK T., Eds), pp. 257-266, LOGO Bydgoszcz.

Kaczmarek S., Michalski J. 1994. Roztocze (Acari; Gamasida) w żerowiskach kornika drukarza (Ips typographus L.) w Polsce [Mites (Acari; Gamasida) from bark beetle (Ips typographus L.) galleries in Poland]. Pr. Kom. Nauk Roln. i Kom. Nauk Leśn. PTPN, 78: 75-82 (in Polish).

Kaczmarek S., Michalski J., Ratajczak E. 1992. Zgrupowania roztoczy (Acari, Gamasida) zasiedlające żerowiska niektórych korników [Mite communities (Acari, Gamasida) from selected bark beetles galleries]. Sylwan, 5: 51-59 (in Polish).

KieŁcZeWSKi B., WiśnieWSKI J. 1983. Bark beetle acarofauna in different types of forest habitat. Part I and II. Introduction and Mesostigmata. Fol. Forest. Pol. A(25): 129-162.

Krysiak D., Błoszyk J., BajaczyK R. 2002. The influence of an urban agglomeration on the dispersion and the abundance of the mites of the suborder Uropodina (Acari: Mesostigmata) in Poznań. In: Studies on Soil Fauna in Central Europe (TaJovský K., BaLí V., PIžL V., Eds), pp. 281-284, ISB AS CR, České Budějovice.

Michalski J., Kaczmarek S., Ratajczak E. 1992. Roztocze (Acari, Mesostigmata) występujące w żerowiskach korników (Coleoptera, Scolytidae) Gorczańskiego Parku Narodowego [Mites (Acari, Mesostigmata) inhabiting bark beetle galleries (Coleoptera, Scolytidae) from Gorczański NP]. Pol. Pismo Entomol. 61: 137-142 (in Polish).

Michalski J., Kaczmarek S., Ratajczak E. 1992a. Z badań nad roztoczami (Acari, Mesostigmata) występującymi w żerowiskach korników (Coleoptera, Scolytidae) [A study of mites (Acari, Mesostigmata) inhabiting bark beetle galleries (Coleoptera, Scolytidae)]. Pol. Pismo Entomol. 61: 143-151 (in Polish).

Michalski J., Ratajczak E., Wiśniewski J. 1985. Roztocze (Acarina: Mesostigmata) towarzyszące kornikom (Coleoptera: Scolytidae) Gór Świętokrzyskich. [Mites (Acarina: Mesostigmata) accompanying bark beetles (Coleoptera: Scolytidae) in the Świętokrzyskie Mountains]. Pr. Kom. Nauk Rol. Kom. Nauk Leśn. PTPN 60: 85-92 (in Polish).

Moser J. C., Bogenshütz H. 1984. A key to the mites associated with flying Ips typographus in South Germany. Z. Angew. Ent. 97: 437-450.

Moser J. C., Eidmann H. H., Regnander J. R. 1989. The mites associated with Ips typographus (Linnaeus) (Coleoptera: Scolytidae) in Sweden. Ann. Entomol. Fenn. 55: 23-27.

Moser J. C., Roton L. M. 1971. Mites associated with southern pine beetles in Allen Parish, Louisiana. Can. Ent. 103: 1775-1798.

NiedbaŁa W., BŁoszyk J., Kaliszewski M., Każmierski A., Olszanowski Z. 1990. Structure of soil mite (Acari) communities in urban green of Warsaw. Fragm. Faun. 33: 21-44.

Skorupski M. 2000. Roztocze z rzędu Gamasida wykazane w Wielkopolskim Parku Narodowym [Mites from the order Gamasida found in the Wielkopolska National Park]. Morena 7: 7-29 (in Polish).

Skorupski M., Gwiazdowicz D. J. 1996. Roztocze (Acari, Mesostigmata) Pienin [Mites (Acari, Mesostigmata) of the Pieniny Mountains]. Fragm. Faun. 39: 223-243 (in Polish).

SŁomian S., MAdEJ G. 2006. A preliminary results on mites (Acari, Gamasida) occurring in decaying wood. In: Advances in Polish Acarology (Gabryś G., Ignatowicz S., Eds), pp. 375-384, SGGW Warszawa. 